\title{
Herbaceous Vegetation-Lotebush [Ziziphus obtusifolia (T. \& G.) Gray var. obtusifolia] Interactions in North Texas
}

M.A. FOSTER, C.J. SCIFRES, AND P.W. JACOBY, JR.

\section{Abstract}

Basal cover and standing crop of herbaceous vegetation were measured during 1979 and 1980 at $0.3-\mathrm{m}$ intervals along transects radiating from individual lotebush canopies in each cardinal direction. Basal covers and standing crops were generally least near the shrubs, regardless of season. However, buffalograss was less abundant in the shrub-free zones than near the lotebush plants. Texas wintergrass basal cover and standing crop were greatest in shrub-free areas except at the north and east driplines, where environmental conditions were apparently ameliorated by the lotebushes. Japanese brome and sand dropseed were most abundant in those zones where buffalograss and Texas wintergrass influences were least. These results indicate that lotebush has a minimal influence on grass cover, and that the major impact is concentrated beneath the shrub canopies.

Lotebush, a spinescent, highly branched shrub with grayishgreen, grooved twigs, is usually 1 to $3 \mathrm{~m}$ tall (Correll and Johnston 1979). Leaves are alternate, ovate to oblong, with serrate margins. Although lotebush occurs throughout Texas at elevations ranging from $1,500 \mathrm{~m}$ to sea level, it is not abundant in east Texas or the northern Panhandle (Vines 1960). It often occurs as a codominant woody plant with honey mesquite (Prosopis glandulosa Torr. var. glandulosa) on rangelands in the Rolling Plains of north Texas.

Lotebush rarely occurs in stands at densities equal to those of honey mesquite. However, it often becomes the dominant woody plant following control of honey mesquite because it resists herbicidal, mechanical, and prescribed burning brush control methods (Scifres and Kothmann 1976, Dodd 1968, Neuenschwander et al. 1976). Previous studies have generally disregarded the ecological significance of lotebush on rangeland. However, it is known that the shrub provides loafing cover for bobwhite quail (Colinus virginianus) (Renwald et al. 1978); produces browse for livestock (Askins and Turner 1972, Ueckert 1980); sprouts profusely following top removal (Scifres and Kothmann 1976); and does not establish but few seedlings in any given year (Speer and Wright 1981).

Woody plants may affect associated herbaceous vegetation by altering species composition, plant density, and plant vigor. One of the most commonly cited interactions between woody shrubs and herbs is competition for soil water (Glendening 1952, Paulsen 1953, Reynolds and Bohning 1956, Cable and Tschirley 1961, Paulsen 1975, Martin 1975). Brock et al. (1978) reported that 3 vegetation zones were associated with honey mesquite in north Texas. Vegetation in the canopy zone (area inside the dripline) was dominated by Texas wintergrass (Stipa leucotricha Trin. \& Rupr.), Arizona cottontop (Digitaria californica [Benth.] Henr.), and buf-

\footnotetext{
Authors are research assistant and Thomas M. O'Connor professor, Department of Range Science, Texas A\&M University, College Station 77843-2126; and associate professor, Texas A\&M University Agricultural Research and Extension Center, P.O. Box 1658, Vernon 76384

This article is approved by the Director, Texas Agricultural Experiment Station, as TA-18795.

The authors wish to thank Julia Scifres for manuscript typing and preparation. The W.T. Waggoner Estate is gratefully acknowledged for furnishing land for this research.

Manuscript accepted November 7, 1983
}

falograss (Buchloe dactyloides [Nutt.] Engelm.). The transition zone, that region between the canopy and interstitial zones, was dominated by Texas wintergrass and buffalograss, while buffalograss was the dominant in the interstitial zone.

Effects of shrubs on forage production are generally perceived to be negative; however, Tiedemann and Klemmedson $(1973,1977)$ have reported that mesquite (Prosopis juliflora [Swartz] DC.) enhances the establishment and growth of herbaceous species. They attributed the positive influence to reduced net radiation and soil temperatures in the canopy zone compared to the interstitial areas. Scifres et al. (1982) found that standing crop of Texas wintergrass increased as huisache (Acacia farnesiana [L.] Willd.) canopy cover increased to $30 \%$ on the Texas Coastal Prairie. Huisache plants apparently ameliorate the environment of the canopy zone as does mesquite, thus providing favorable conditions for Texas wintergrass growth and development.

The objective of this study was to quantify the ecological relationship between lotebush and the native herbaceous vegetation in the Rolling Plains.

\section{Experimental Procedures}

\section{Study Area}

Research was conducted approximately $20 \mathrm{~km}$ south of Vernon, Texas, on the W.T. Waggoner Estate $\left(33^{\circ} 56^{\prime} \mathrm{N}, 99^{\circ} 16^{\prime} \mathrm{W}\right)$. Site elevation was $336 \mathrm{~m}$. Mean annual temperatures at Vernon range from a minimum of $5.7^{\circ} \mathrm{C}$ in January to a maximum of $29.8^{\circ} \mathrm{C}$ in July (USDC 1980). Average number of frost-free growing days is approximately 222 , and extends from late March to early November. Annual precipitation averages $56.2 \mathrm{~cm}$ and ranges from $2.4 \mathrm{~cm}$ in January to $11.9 \mathrm{~cm}$ in May.

Soil at the study site was Tillman clay loam (Fine, mixed, thermic, Typic Paleustolls), which is a deep, well-drained, slowly permeable soil formed in clayey alluvium derived from redbed clays and shales. Range site classification was Clay Loam (USDA 1974). Climax vegetation is dominated by sideoats grama (Bouteloua curtipendula [Michx.] Torr.), vine-mesquite (Panicum obtusum H.B.K.), Arizona cottontop, and buffalograss. Forbs and woody plants account for less than $5 \%$ of the climax vegetation.

Herbaceous vegetation at the study site was dominated by buffalograss, Texas wintergrass, Japanese brome (Bromus japonicus Thunb.), and sand dropseed (Sporobolus cryptandrus [Torr.] Gray). Heath aster (Aster ericoides L.) and common broomweed (Xanthocephalum dracunculoides [DC.] Shinners) were the most common forbs.

Lotebushes 1.5 to $1.9 \mathrm{~m}$ tall were prevalent on the study area and occurred in association only with scattered, small honey mesquite plants. Honey mesquite on the site was hand grubbed in 1951 and the remainder basally treated with diesel oil in 1966. Grazing by domestic livestock had been limited to the dormant season for at least 10 years. 


\section{Methods}

Transects, each $3 \mathrm{~m}$ long and originating from the shrub canopy dripline, were established in each cardinal direction from 20 lotebush plants. Basal vegetation cover was estimated in June 1979 by placing a 10-point, inclined sampling frame every $0.3 \mathrm{~m}$ along the transect lines and recording each contact (bare soil, mulch, or plant bases). Basal cover was also estimated along 20 transects ( $6 \mathrm{~m}$ long) located in adjacent shrub-free areas where shrub canopy influence and root penet ration were assumed to be negligible (no closer than $20 \mathrm{~cm}$ to the nearest lotebush).

Herbaceous standing crops were estimated in spring (mid May) and fall (mid September) of both years. Since herbaceous vegetation was absent at the bases of the lotebush plants, circular quadrats $\left(0.25 \mathrm{~m}^{2}\right)$ were located along each direction transect at the canopy dripline and $2.3 \mathrm{~m}$ outward from the dripline. Two quadrats were also randomly located along each of the 20 transects established in the shrub-free areas. Standing crop was clipped at the soil surface by species, dried in a forced air oven at $60^{\circ} \mathrm{C}$ to a constant weight, and weighed.

\section{Statistical Analyses}

Variation in basal vegetation cover and herbaceous standing crop as influenced by lotebush presence was evaluated by analysis of variance after transformation of data to $\log (X+1)$. Means were separated by Tukey's $w$-procedure $(\alpha=0.05)$ (Snedecor and Cochran 1980). Four data sets (zones) were arbitrarily created to compare the basal cover adjacent to the lotebushes and in shrub-free areas. Zone 1 included $0.3,0.6$, and $0.9 \mathrm{~m}$ from the lotebush driplines; zone 2 represented the $1.2,1.5$, and $1.8 \mathrm{~m}$ distances; zone 3 included 2.1, 2.4, 2.7, and $3.0 \mathrm{~m}$ from the canopies; and zone 4 represented the shrub-free area.

\section{Results}

\section{Basal Vegetation Cover}

Species composition, based on basal cover, varied as a function of direction (Table 1) and distance (Table 2) from the lotebush

Table 1. Average basal vegetation cover (\%) for four species in each cardinal direction to $3 \mathrm{~m}$ from the lotebush canopies in June 1979 on the Rolling Plains near Vernon, Texas.

\begin{tabular}{lcccc}
\hline \hline & \multicolumn{4}{c}{ Species 1} \\
\cline { 2 - 5 } Direction & Buffalograss & $\begin{array}{c}\text { Texas } \\
\text { wintergrass }\end{array}$ & $\begin{array}{c}\text { Japanese } \\
\text { brome }\end{array}$ & $\begin{array}{c}\text { Sand } \\
\text { dropseed }\end{array}$ \\
\hline South & $10.7 \mathrm{a}$ & $2.7 \mathrm{a}$ & $1.1 \mathrm{ab}$ & $0.5 \mathrm{a}$ \\
West & $11.2 \mathrm{a}$ & $2.3 \mathrm{a}$ & $1.7 \mathrm{~b}$ & $0.6 \mathrm{a}$ \\
North & $11.6 \mathrm{a}$ & $1.8 \mathrm{a}$ & $0.6 \mathrm{a}$ & $0.6 \mathrm{a}$ \\
East & $10.5 \mathrm{a}$ & $2.5 \mathrm{a}$ & $1.1 \mathrm{ab}$ & $0.7 \mathrm{a}$ \\
\hline
\end{tabular}

Means within columns followed by the same letter are not significantly different ( $\alpha=$ 0.05).

plants. However, direction by distance interactions were not significant; and buffalograss was the dominant species, regardless of direction or distance. Basal covers of buffalograss, Texas wintergrass or sand dropseed did not vary significantly among directions (Table 1). However, greatest cover of Japanese brome occurred on the west side of the shrubs and least on the north side.

Buffalograss basal cover did not differ among the zones adjacent to the shrubs (zones 1, 2 and 3) (Table 2). Cover of buffalograss in the shrub-free zone was significantly less than that immediately adjacent (zone 1) to the lotebush. Average basal cover of Texas wintergrass did not vary significantly among zones 1,2 and 3 , but cover bordering the lotebushes (zones 1 and 2) was less than that on shrub-free areas. Cover of Japanese brome and sand dropseed varied little with proximity to the lotebushes.

\section{Herbaceous Standing Crop}

Herbaceous standing crops of the four grasses varied little with direction or distance from the lotebushes. Buffalograss standing crop tended to be greatest along the north transects and least on the east (Table 3). There was a propensity for most buffalograss herbage to be produced at $2.3 \mathrm{~m}$ from the lotebushes and least at the dripline, regardless of direction. Texas wintergrass standing crop was generally greatest in the shrub-free areas except at the east and north driplines (Table 4). Standing crop of Japanese brome tended to be greatest at the north and west driplines during spring 1979. However, at the fall 1980 harvest, the greatest standing crop occurred on the shrub-free areas (Table 5). A significant direction by distance interaction occurred with the spring 1979 harvest, but was not present in analyses of other sampling dates. Sand dropseed standing crop was usually greater at the shrub driplines, particularly at the west and south transects (Table 6).

\section{Discussion}

Direction and distance from the lotebushes exerted little influence on herbaceous basal covers with one exception. Basal cover of buffalograss was less within $0.9 \mathrm{~m}$ of the lotebushes than at 1.2 to $3.0 \mathrm{~m}$ from the canopies and in the shrub-free areas. Root distribution patterns of lotebush (Foster 1983) indicate that exploitation of available soil water would be greatest within the canopy zone. Presumably, the reduced buffalograss cover near the shrubs, as compared to the intersitial zones, was a result of the competitive interaction between lotebush and buffalograss for soil water.

Texas wintergrass, a deep-rooted, perennial bunchgrass also occurred less frequently near the shrubs than in the interstitial zones. Lotebush lateral roots may extend into zones 1 and 2 , and effectively compete with Texas wintergrass for soil water. These roots may be deep enough to prevent interaction with the shallowrooted buffalograss, but may intermingle with the greater root densities of bunchgrasses. Increased abundance of Texas wintergrass may, in part, also account for the lower cover of buffalograss in the shrub-free zone.

Direction and distance from the lotebushes also imposed only minor changes in herbaceous standing crops. The least buffalograss standing crop at the dripline, again, would indicate shrub/ grass competition for soil water.

The east and north driplines apparently provided environmental regimes preferred by Texas wintergrass. Scifres et al. (1982) concluded that huisache ameliorated the environment of the canopy zone in south Texas, thus providing favorable conditions for Texas wintergrass. Texas wintergrass produced the most herbage in the honey mesquite canopy zone on the Rolling Plains (Brock 1978). However, although abundance of Texas wintergrass in association

Table 2. Average basal vegetation cover $(\%)$ in four zones associated with lotebush in June 1979 on the Rolling Plains near Vernon, Texas.

\begin{tabular}{lccccc}
\hline \hline & & \multicolumn{3}{c}{ Species 1} \\
\cline { 2 - 5 } $\begin{array}{l}\text { Distance from } \\
\text { canopy }(\mathrm{m})\end{array}$ & Zone & Buffalograss & $\begin{array}{c}\text { Texas } \\
\text { wintergrass }\end{array}$ & $\begin{array}{c}\text { Japanese } \\
\text { brome }\end{array}$ & $\begin{array}{c}\text { Sand } \\
\text { dropseed }\end{array}$ \\
\hline $0.3-0.9$ & 1 & $8.9 \mathrm{a}$ & $2.4 \mathrm{a}$ & $0.7 \mathrm{a}$ & $0.8 \mathrm{a}$ \\
$1.2-1.8$ & 2 & $12.3 \mathrm{a}$ & $2.0 \mathrm{a}$ & $1.4 \mathrm{a}$ & $0.5 \mathrm{a}$ \\
$2.1-3.0$ & 3 & $11.5 \mathrm{a}$ & $3.1 \mathrm{ab}$ & $1.2 \mathrm{a}$ & $0.6 \mathrm{a}$ \\
Shrub-free & 4 & $5.5 \mathrm{~b}$ & $3.6 \mathrm{~b}$ & $1.1 \mathrm{a}$ & $0.8 \mathrm{a}$ \\
\hline
\end{tabular}

'Means within columns followed by the same letter are not significantly different $(\alpha=0.05)$. 
Table 3. Average herbaceous atanding crop $\left(\mathrm{g} / \mathrm{m}^{2}\right)$ of bufralograss at the lotebush driplines, $2.3 \mathrm{~m}$ from the driplines and on adjacent shrub-free areas in the spring and fall of 1979 and 1980 on the Rolling Plains near Vernon, Texas.

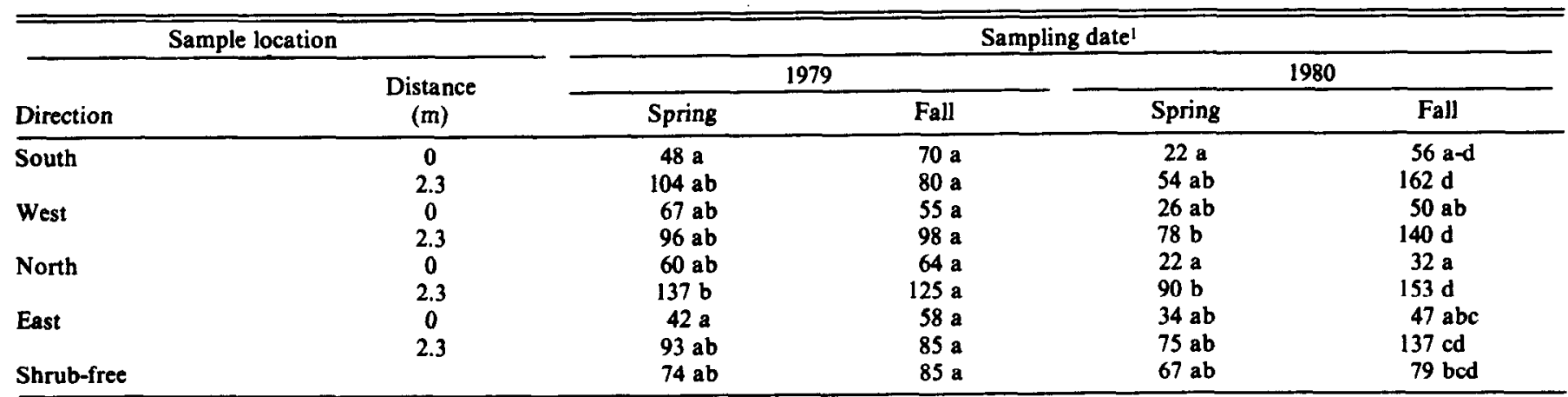

Means within columns followed by the same letter are not significantly different $(\alpha=0.05)$.

Table 4. Average herbaceous standing crop $\left(\varepsilon / \mathrm{m}^{2}\right)$ of Texas winterzmas at the lotebush driplines, $2.3 \mathrm{~m}$ from the driplines and on adjacent shrub-free areas in the spring and fall of 1979 and 1980 on the Rolling Plains near Vernon, Texas.

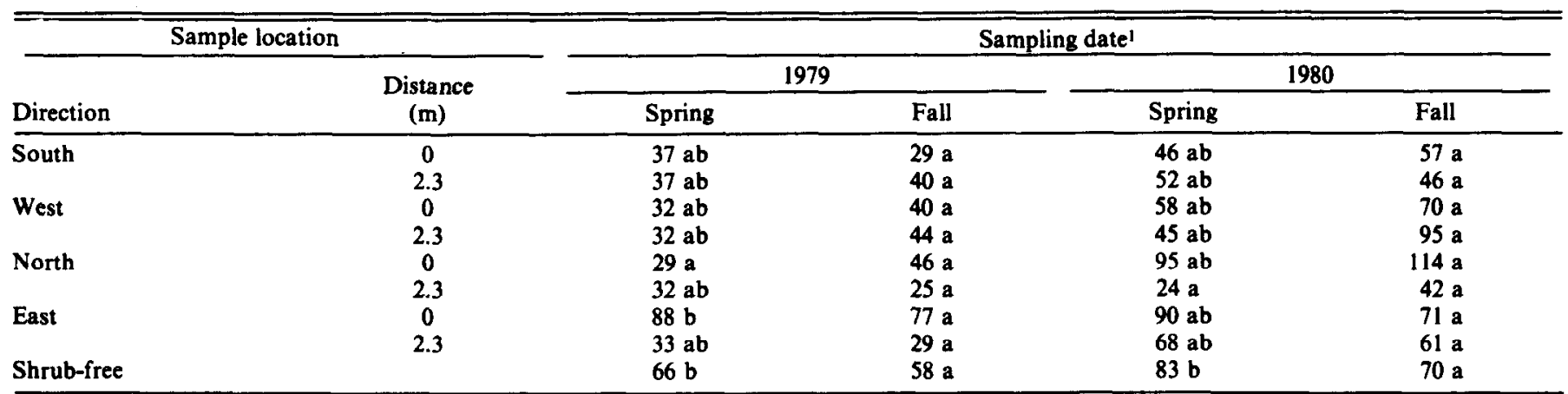

'Means within columns followed by the same letter are not significantly different $(\alpha=0.05)$.

Table 5. Average berbaceous standing crop $\left(\mathrm{g} / \mathrm{m}^{2}\right)$ of Japanese brome at the lotebush driplines, $2.3 \mathrm{~m}$ from the driplines and on adjacent shrub-free areas in the spring and fall of 1979 and 1980 on the Rolling Plains near Vernon, Texas.

\begin{tabular}{|c|c|c|c|c|c|}
\hline \multicolumn{2}{|c|}{ Sample location } & \multicolumn{4}{|c|}{ Sampling date ${ }^{l}$} \\
\hline \multirow[b]{2}{*}{ Direction } & \multirow{2}{*}{$\begin{array}{l}\text { Distance } \\
\text { (m) }\end{array}$} & \multicolumn{2}{|c|}{1979} & \multicolumn{2}{|c|}{1980} \\
\hline & & Spring & Fall & Spring & Fall \\
\hline South & $\begin{array}{c}0 \\
23\end{array}$ & $\begin{array}{r}4 \mathrm{a} \\
8 \mathrm{a}\end{array}$ & $1 a$ & $11 \mathrm{a}$ & 5 a \\
\hline West & $\begin{array}{c}2.3 \\
0 \\
2.3\end{array}$ & $\begin{array}{c}18 \mathrm{ab} \\
8 \mathrm{a} \\
12 \mathrm{ab}\end{array}$ & $\begin{array}{l}3 \mathrm{a} \\
4 \mathrm{a}\end{array}$ & $\begin{array}{l}18 \mathrm{a} \\
10 \mathrm{a}\end{array}$ & $\begin{array}{l}20 \mathrm{ab} \\
18 \mathrm{ab} \\
14 \mathrm{ab}\end{array}$ \\
\hline North & $\begin{array}{c}0 \\
2.3\end{array}$ & $\begin{array}{l}30 \mathrm{~b} \\
21 \mathrm{ab}\end{array}$ & $\begin{array}{l}6 \mathrm{a} \\
5 \mathrm{a}\end{array}$ & $\begin{array}{r}13 a \\
7 a\end{array}$ & $\begin{array}{l}13 \mathrm{ab} \\
23 \mathrm{ab}\end{array}$ \\
\hline $\begin{array}{l}\text { East } \\
\text { Shrub-free }\end{array}$ & $\begin{array}{c}0 \\
2.3\end{array}$ & $\begin{array}{c}2 \mathrm{a} \\
17 \mathrm{ab} \\
21 \mathrm{~b}\end{array}$ & $\begin{array}{l}4 \mathrm{a} \\
2 \mathrm{a} \\
3 \mathrm{a}\end{array}$ & $\begin{array}{r}11 \mathrm{a} \\
5 \mathrm{a} \\
10 \mathrm{a}\end{array}$ & $\begin{array}{c}15 \mathrm{ab} \\
16 \mathrm{ab} \\
24 \mathrm{~b}\end{array}$ \\
\hline
\end{tabular}

'Means within columns followed by the same letter are not significantly different $(\alpha=0.05)$.

Table 6. A verage herbaceous standing crop $\left(g / m^{2}\right)$ of sand dropseed at the lotebush driplines, $2.3 \mathrm{~m}$ from the driplines and on adjacent shrub-free areas in the spring and fall of 1979 and 1980 on the Rolling Plains near Vernon, Texas.

\begin{tabular}{|c|c|c|c|c|c|}
\hline \multicolumn{2}{|c|}{ Sample location } & \multicolumn{4}{|c|}{ Sampling date } \\
\hline \multirow[b]{2}{*}{ Direction } & \multirow{2}{*}{$\begin{array}{c}\text { Distance } \\
\text { (m) }\end{array}$} & \multicolumn{2}{|c|}{1979} & \multicolumn{2}{|c|}{1980} \\
\hline & & Spring & Fall & Spring & Fall \\
\hline South & 0 & $31 \mathrm{~b}$ & $51 \mathrm{ab}$ & $24 \mathrm{ab}$ & 35 bc \\
\hline & 2.3 & $11 \mathrm{ab}$ & $10 a b$ & $5 a b$ & $8 \mathrm{abc}$ \\
\hline West & 0 & $22 \mathrm{ab}$ & $58 \mathrm{~b}$ & $49 \mathrm{~b}$ & $54 \mathrm{c}$ \\
\hline & 2.3 & $14 a b$ & $17 a b$ & $6 a b$ & $2 \mathrm{a}$ \\
\hline North & 0 & $20 \mathrm{ab}$ & $36 \mathrm{ab}$ & $32 \mathrm{ab}$ & $11 a b c$ \\
\hline & 2.3 & $7 \mathrm{ab}$ & $19 \mathrm{ab}$ & $16 \mathrm{ab}$ & $10 \mathrm{abc}$ \\
\hline East & 0 & $3 a$ & $9 \mathrm{a}$ & $6 a b$ & $33 \mathrm{abc}$ \\
\hline & 2.3 & $11 a b$ & $9 a$ & $4 a$ & $4 a b$ \\
\hline Shrub-free & & $10 a b$ & $19 \mathrm{ab}$ & $2 a$ & $24 \mathrm{abc}$ \\
\hline
\end{tabular}

Means within columns followed by the same letter are not significantly different $(\alpha=0.05)$. 
with the lotebushes varied with exposure, average standing crop was consistently greater in the shrub-free zone than near the woody plants.

Mean standing crop of Japanese brome, an annual, cool-season grass, was usually greatest in the shrub-free areas. However, Japanese brome production was sometimes greater at the shrub driplines where Texas wintergrass was less productive. The significant direction by distance interaction at the spring 1979 harvest was a result of the relatively large standing crop $\left(30 \mathrm{~g} / \mathrm{m}^{2}\right)$ produced at the north dripline. Japanese brome could not effectively compete with the deeper-rooted, perennial Texas wintergrass at the other dripline locations. Sand dropseed frequently yielded the greatest biomass at the shrub driplines where influence of the dominants, buffalograss and Texas wintergrass, was least.

Results of this study indicate that lotebush does not strongly compete with the herbaceous vegetation. The major impact of lotebush on rangeland in north Texas is concentrated directly beneath the shrub canopy with little effect from the dripline

\section{Literature Cited}

Askins, G.D., and E.E. Tumer. 1972. A behavioral study of Angora goats on west Texas range. J. Range Manage. 25:82-87.

Brock, J.H., R.H. Hass, and J.C. Shaver. 1978. Zonation of herbaceous vegetation associated with honey mesquite in northcentral Texas. Proc. Internat. Range Cong. 1:187-189.

Cable, D.R., and F.H. Tschirley. 1961. Responses of native and introd uced grasses following aerial spraying of velvet mesquite in southern Arizona. J. Range Manage. 14:155-159.

Correll, D.S., and M.C. Johnston. 1979. Manual of the vascular plants of Texas. Texas Res. Found., Renner, Texas.

Dodd, J.D. 1968. Mechanical control of pricklypear and other woody species on the Rio Grande Plains. J. Range Manage. 21:366-370.

Foster M.A. 1983. The ecology of lotebush (Ziziphus obtusifolia T. \& G.) Gray var. obtusifolia) in north Texas. Ph.D. Diss. Texas A\&M Univ., College Station, Texas. outward

Glendening, G.E. 1952. Some quantitative data on the increase of mesquite and cactus on a desert grassland range in southern Arizona. Ecology 33:319-328.

Martin, S.C. 1975. Ecology and management of southwestern semidesert grass-shrub ranges: The status of our knowledge. USDA For. Serv. Res. Paper. RM-156.

Neuenschwander, L.F., S.C. Bunting, and H.A. Wright. 1976. Long term effect of fire on lotebush. p. $46 \mathrm{~m}$ : R.E. Sosebee and H.A. Wright (Ed.), Noxious Brush and Weed Control Res. Highlights, Vol. 7. Texas Tech Univ., Lubbock.

Paulsen, H.A. 1953. A comparison of surface soil properties under mesquite and perennial grass. Ecology 34:727-732.

Paulsen, H.A. 1975. Range management in the central and southern Rocky Mountains: A summary of the status of our knowledge by range ecosystems. USDA For. Serv. Res. Paper RM-154.

Renwald, J.D., H.A. Wright, and J.T. Flinders. 1978. Effect of prescribed fire on bobwhite quail habitat in the Rolling Plains of Texas. J. Range Manage. 31:65-69.

Reynolds, H.G., and J.W. Bohning. 1956. Effects of burning on a desert grass-shrub range in southern Arizona. Ecology 37:769-777.

Scifres, C.J., and M.M. Kothmann. 1976. Site relations, regrowth characteristics, and control of lotebush with herbicides. J. Range Manage. 29:154-157.

Scifres, C.J., J.L. Mutz, R.E. Whitson, and D.L. Drawe. 1982. Interrelationships of huisache canopy cover with range forage on the Coastal Prairie. J. Range Manage. 35:558-562.

Snedecor, G.W., and W.G. Cochran. 1980. Statistical Methods. lowa State Univ. Press. Ames.

Speer, E.R., and H.A. Wright. 1981. Germination requirements of lotebush (Ziziphus obtusifolia var obtusifolia). J. Range Manage. 34:365-368.

Tiedemann, A.R., and J.O. Klemmedson. 1973. Effect of mesquite on physical and chemical properties of the soil. J. Range Manage. 26:27-29.

Tiedemann, A.R., and J.O. Klemmedson. 1977. Effect of mesquite trees on vegetation and soils in the desert grassland. J. Range Manage. 30:361-376.

Ueckert, D.N. 1980. Manipulating range vegetation with prescribed fire, $p$. 27-44 In: L.D. White (Ed.), Prescribed Range Burning in the Edwards Plateau of Texas. Proc. Symp. Texas Agr. Ext. Ser. College Station.

U.S. Department of Agriculture. 1974. Range site descriptions. Area No. 3. Section 11-E. p. 5.1-5.3 Soil Conserv. Ser. Temple, Texas.

U.S. Department of Commerce. 1980. National Oceanic and Atmospheric Administration. Climatological Data, Texas. Vol. 85, No. 13.

Vines, R.A. 1960. Trees, Shrubs, and Woody Vines of the Southwest. Univ. Tex. Press, Austin.

\section{POSITION ANNOUNCEMENT}

Faculty Position in Range Management Department of Forestry and Resource Management University of California, Berkeley

Position-The position can be filled at the Assistant or Associate Professor level, depending on the qualifications of the individual selected. Appointment will be half in teaching and half in research on an $\mathbf{1 1}$ month basis.

Qualifications-Applicants must have a Ph.D. degree in Range Management or a closely related field. Preference will be given to individuals with expertise in the assessment and management of rangeland ecosystems. Experience in dealing with land management agencies is desirable. Doctoral candidates expecting to complete degree requirements by July 1,1985 are encouraged to apply.

Responsibilities- a) Teach an undergraduate course in Principles of Range Management and a graduate course in Rangeland Ecosystem Measurement and Analysis. Share responsibilities as advisor for undergraduate and graduate students in Range Management. Supervise graduate student research. b) Initiate and direct original research in the area of management of rangeland ecosystems. Develop techniques for measurement and analysis of rangeland ecosystems for different resource values. Work closely with land management agencies and other resource managers.
Appointment-Appointment to begin July 1, 1985 or as soon thereafter that a suitable applicant is found.

Applications-Send resume, academic transcripts, and the names of at least three references to Chairman, Range Management Search Committee, 145 Mulford Hall, University of California, Berkeley, CA 94720 . Deadline for applications is November 1, 1984.

\section{The University of California Is an Equal Opportunity, Affirmative Action Employer}

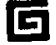

Assistant Profesor Range Science. Ph.D in Range Science or closely allied area for nine-month, tenure-track teaching position in Range Management, Range Ecology and Range Plants. Summer contract dependent upon institutional need. Secondary teaching area of general agronomy or agricultural economics desirable. Individual research encouraged $-2,000$ acres of university range and pasture available. Previous teaching and student advising preferred. Send resume and request for application form to Tarleton State University, W.H. Newton, Head, Department of Agriculture, Stephenville, TX 76402. (817) 968-9222. Closing September 15, 1984. 